\title{
ENHANCING INNOVATION AND SUSTAINABILITY REGIONAL TOURISM DEVELOPMENT IN THE ERA INDUSTRY 4.0
}

\author{
Isdarmanto $^{1,2}$, Christantius Dwiatmadja, Hari Sunarto, and Antonius Suryo Abdi \\ ${ }^{1}$ Satya Wacana Christian University, Salatiga Indonesia \\ ${ }^{2}$ Ambarrukmo Tourism Institute, Yogyakarta Indonesia \\ pais.atonk@gmail.com
}

\begin{abstract}
This study discusses how the sustainability tourism development strategy in every regency be able to improve the social welfare of local communities. The decentralization program has given freedom and policy to enhance the role of regional tourism to be more competitive. This study is using qualitative methods to be able to explore the empiric phenomenon of deeper problems that expected to be used as a reference for the strategy development of regional tourism applied in global and digital era, which is very competitive and professional through the strategy of well structure and systematic tourism program to be effective and efficient.
\end{abstract}

Keywords: Sustainability; social welfare; development strategy.

\section{INTRODUCTION}

The development of Tourism in Indonesia shows a very significant increase with proven growth in tourism in each region, the economic development of society, the negative implications are city congestion and especially in tourist objects, especially during the holidays, making transportation and traffic problems very difficult be controlled. This research discusses how the development of the Tourism industry in the 4.0 era to be able to compete and maintain long-term business continuity in global competition. Benchmarks for tourism growth in the 4.0 era are aspects of the growth of digital communication networks, socioeconomic developments and the welfare of society in each region that is increasingly advanced according to the concept of smart cities in Indonesia. The aim of tourism development is to increase the growth of existing regional tourism destinations, the increasing number of tourist visits both domestic and foreign as well as the availability of adequate tourism service products. Local government policy always wants to create the welfare of the local community as a tourist destination to be achieved. In line with the central government policy to be able to provide opportunities for each region to achieve mutual prosperity in accordance with the regional autonomy program. Through the decentralization program, each region tries to build its own region, so that a strategy of innovation 
that is programmed and sustainable, measurable and systematic is needed to achieve the desired goals.

Special regions of Yogyakarta in all districts: Sleman, Bantul, Kuloprogo, Gunung Kidul regencies and the municipality have been able to create the local attractions of their respective interests from the role of investors and tourism activists. Along the coast of Kulonprogo, Bantul and Gunung Kidul districts, they have been able to develop coastal areas with their uniqueness such as mangrove forests, Glagah, Goa Cemara, Baru beach, Samas, Parangtritis, Baron, Kukup, Krakal, Cial beach, Jogan, Gesing, Indrayanti, etc. Sleman Regency with the development of the Merapi area, world landmarks, Stonehenge, Merapi Museum, Sentanu batik museum, Lava tour, Lantern Tourism in Kaliurang and the Municipality of Yogya with the development of the Tugu, Malioboro, Zero Point, and southern square area.

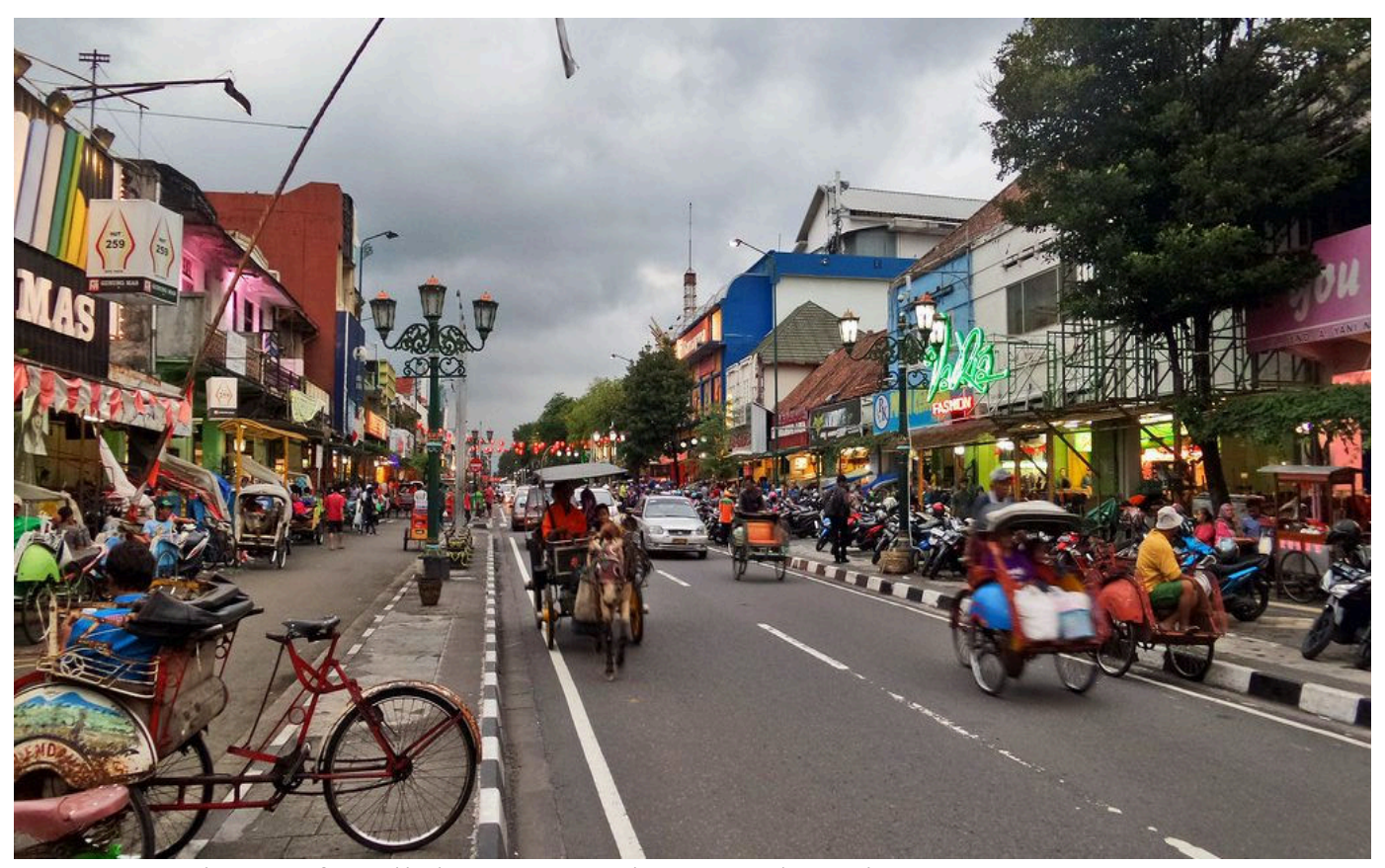

Image: Heritage of Malioboro Yogyakarta, Indonesia

(Source: Yogyess.com 2019)

\subsection{Rational and Justification}

According to the experience of several researchers, it is stated that tourism development is not only concerned with tourists, but also involves the interests of local, regional and national communities which are generally associated with the development and development of tourist destinations. Regional tourism destination management must be done professionally and globally who are able to take part in the development of the digital era. "The more digital, the more professional, the more digital the more global." Development of regional tourism destinations that are able to provide attractions, security, comfort, convenience and benefits for tourists and the environment to improve the lives of many people, by using current digital technology developments this. Furthermore (Yoeti, 2006) states in the development of tourism has four pillars or attributes as follows: a). The 
responsibility for the environment in terms of protection, conservation or expansion of natural resources and the physical environment to ensure long-term life and the sustainability of existing ecosystems, nature tourism that will produce the concept of sustainable tourism; b). The vitality of the local economy that is able to drive the growth and development of local businesses and the economy of the community to ensure economic strength and sustainability, for example the impact of the development of tourist sites will usually be followed by increased local economic activity; c). Cultural sensitivity that can encourage the attractiveness and appreciation of tourists for existing customs and cultural diversity and to ensure the continuity of local culture as well. For example through cultural tourism, so that tourists will get to know the culture of the region or other countries that lead to an appreciation of cultural richness; d). Wealth of experience by creating attractions that can enrich and enhance a more satisfying tourist experience, through active participation in the understanding and involvement of individuals with nature, humans, places and culture.

Soetomo (2006) added that in order for the tourism development process to be sustainable, a cumulative increase in community participation through joint actions in various activities should be sought. The joint action will be more effective if it involves a common interest, such as building public roads, clean water for the community, productive economic endeavors and the like, so that it will foster mutual trust and shared responsibility. With this background it is unfortunate if the diverse potential of DIY is not empowered and developed to preserve its existence in the competitive competition of world tourism today. Related to the decision of the United Nations conference attended by world leaders from 189 countries in 2012 and created a joint agreement that the concept of sustainable tourism development with "seventeen sustainable development goals". The Indonesian government agreed to agree on the concept of sustainable development. The UN Declaration sets out a set of targets that are socialized universally and measured by balancing three dimensions of sustainable development, namely; (1) environment, (2) social, and (3) economy. UN resolution based on "sustainable development goals" is sustainable development that is focused on aspects: planet, people and profit. Understanding the planet is a Mother Nature which is oriented to aspects of environmental development and preservation of nature. Green eco-tourism development (green tourism) is currently an application of "The Global Goals for Sustainable Development". The development of sustainable global tourism is a set of targets which for the social and economic aspects of society end poverty, fight inequality and injustice and improve climate change that benefits everyone until 2030 (António Guterres, 2019)

Yoeti (2006) also stated that tourism development planning includes: (1). Give direction; (2). Guiding cooperation; (3). Creating coordination; (4). Guaranteeing achievement; (5). To minimize risk: (6). Encourage the implementation of work. In the seminar on spatial renewal, for the improvement of life in the region, a tourism management approach is needed. (Nuryanti, Wiendu, 2010), provides details that in the development of tourism more broadly as follows: (1). Give the right direction for the development of tourism resources owned. So that tourism is expected to grow in a sustainable manner, have competitiveness for regional development, and can improve the welfare of the community. (2). Regulate the role of each Penta helix activist across sectors so as to encourage the 
development of ecotourism in a energetic and integrated manner. (Jhingan, 1999) (Kuznets \& Simon, 1999) defines that economic growth as a goal of long-term increase in creating the ability of a country to provide more and more types of economic goods to its population, this capability grows in accordance with technological progress, as well as institutional adjustments and ideological requirements (Jhingan, 1999).

Competency development between individuals as entrepreneurs is also one of the most influential factors in the process of creating new businesses, in promoting growth, and creating success in a business venture that is in the community. (Berryman, J. C, \& .Frey; Murali, Mohani, \& Yuzliani, 2007). The ability to make innovations and the courage to apply innovations in new businesses that are built to open jobs, reduce unemployment, and improve the welfare of the community. The higher the number of entrepreneurs, the higher the economic growth (De Pillis, E., \& Reardon, K. K., 2007).

(Tarmuji \& Tarsis, 2000) explained that, an entrepreneur is a person who has a prominent personal quality that can be seen from the attitudes, motivations and behaviors that underlie it. Entrepreneurs have an important role in more productive activities that can drive economic growth in a country. Entrepreneurs innovate the production process and are willing to take risks in doing every business they manage. With the ability to create innovation and the courage to implement innovation in companies, entrepreneurs are able to set up companies with new businesses that are built to create jobs, reduce unemployment, and create microeconomics to improve people's welfare. More and more successful entrepreneurs can increase economic growth higher. As such it is aligned with the entrepreneurship-based educational curriculum program which has played an important role in developing entrepreneurial competencies and fostering interest in their students in doing business.

It must be understood that economic development includes community efforts to develop economic activities and also increase the level of community income, but overall economic development efforts must also include social, political, and cultural development efforts of the community. Economic development is generally defined as a process that causes a society's per capita income to increase over a long-term period. (Sadono Sukirno, 1985). While (Kuznets \& Simon, 1999) defines economic growth as the goal of long-term improvement in creating the ability of a country to provide more economic goods for its population, this ability grows according to technological advancements, as well as institutional and ideological adjustments (Jhingan, 1999).

Berryman, J. C, \& .Frey, Murali, Mohani \& Yuzliani (2007).states the development of competencies among individuals as entrepreneurs also has one of the most influential factors in the process of creating new business, in promoting growth, and creating success in business adventures. In the development of the restaurant business it is now increasingly understood that every individual and company has an entrepreneur who must be able to create a breakthrough in accordance with the needs of competence, abilities and expertise possessed. It does not matter how small businesses need to be pursued, and it is believed to be able to produce profits so that the results of efforts remain to meet the business survival needs. It would be better for every individual as an entrepreneur to create jobs for the surrounding environment with a labor-intensive system, so that indirectly 
provide benefits and value for the local community to improve their social welfare. Labor intensive is directed to public works, such as rural infrastructure development, environmental sanitation development, reforestation activities, according to the needs of each regional style business.

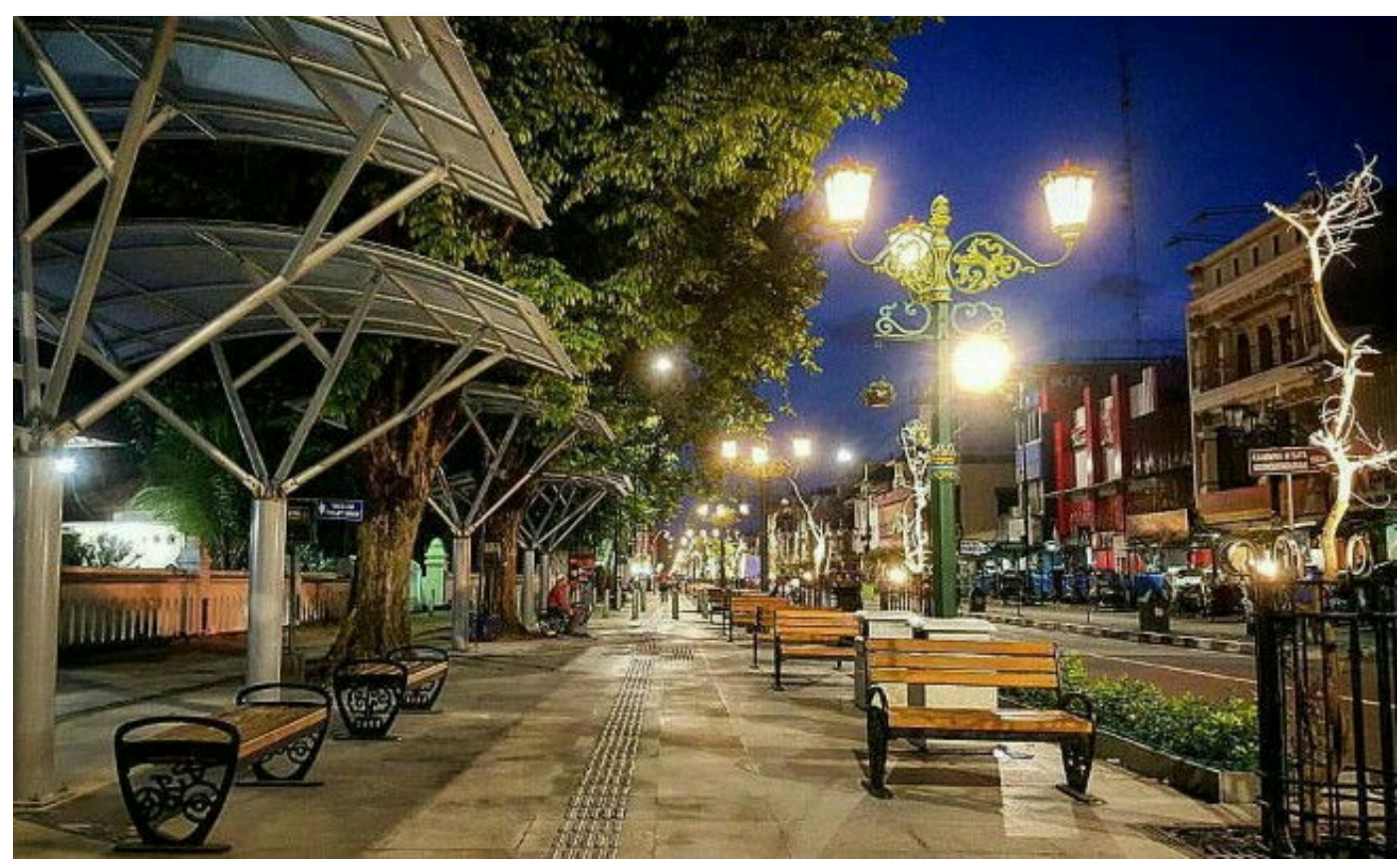

Images: Pedestrian area of Malioboro Yogyakarta, Indonesia

Source: yogyess.com 2019.

\subsection{Problem Statement.}

In many circumstances the development of tourism cannot be separated from the empowerment of the social capital of the local communities involved in it. In addition, it is stated that the very complex elements of community development can be described as: planned programs focusing on the total needs of community (Holistic) concerns. The ability to encourage community self-motivation (empowerment), it also requires technical assistance from the government and private institutions or voluntary organizations, including personnel, equipment, materials or funds for partnerships. Able to bring together various fields of specialization such as agriculture, animal husbandry, public health, education, family welfare, femininity, youth, etc., helping the local community. Ways and steps in increasing the role of society, among others, community participation in general is a human-oriented process and its relationship with other humans. And most importantly, it is emphasized that trainers are facilitators, providers of technical assistance, but not as community instructors, because the aim is for people to develop independence and not create their own dependencies from others (Effendi, 2003).

According to (Suryono, \& Agus, 2004), the strategy is in principle relevant to the problem: implementing the policy, determining the objectives to be achieved, and determining the way or method for the use of infrastructure. The strategy is always about three things: goals, facilities and ways. Therefore, strategy must also be supported by the ability to anticipate opportunities. In carrying out its functions 
and roles in the development of regional tourism, local governments must make efforts in developing tourism infrastructure. According to (Sekartjakrarini, 2007) a member of Tourism Concern for environmental experts, as executive director of IDEA (Innovative Development of Eco Awareness) states that if an area develops tourism, negative side effects can occur. Forests, coastal areas, small islands, villages, all settlements and old cities are developed for tourism which are often inundated by development related projects and not all are environmentally friendly. Therefore, the government needs to participate in monitoring the management of regional tourism development to take certain steps, so that operators and developers do not cause damage to the natural environment. While future global tourism destinations require the availability of products, which are diverse, unique, and of high quality (high-value production of unique commodities) and leave behind largescale tourism products.

\subsection{Objectives.}

In this study relies that tourism development requires the participation of information from all relevant stakeholders, as well as strong political leadership to ensure broad participation and consensus building. Achieving sustainable tourism is a continuous process and requires continuous monitoring of all impacts, introducing necessary preventive and corrective measures when needed. Sustainable tourism must also maintain a high level of tourist satisfaction and ensure meaningful experiences for tourists, increase their awareness of sustainability issues and promote sustainable tourism practices among them (Ashley \& UNWTO, 2002) Development of sustainable tourism requires the participation of all parties, related information and strong political leadership to ensure broad participation and consensus building. Sustainable tourism is a continuous process and requires ongoing impact monitoring, for prevention and or improvement needed in the future. For the development of sustainable tourism must also maintain aspects of tourist satisfaction and ensure their experiences are good and useful, and increase their awareness of the existing problems and even be able to promote sustainable tourism development programs.

Ardiwijaya (2004) states that sustainable global tourism emphasizes the organization of alternative and responsible tourism to meet the needs and aspirations of the latest human being without compromising the potential fulfillment of needs by applying the principles of economically feasible, environmentally viable, socially acceptable), and appropriate technology (technologically appropriate). Furthermore (Ardiwijaya, 2004) The Government of the Special Region of Yogyakarta (DIY) should have come to understand sustainable development in accordance with the agreement of The Global Goals for Sustainable Development in point 11, namely "Sustainable cities and communities" by applying more total and comprehensive development of the Yogyakarta city area. Widodo (2008) links the development of tourism with several things that need to be considered to ensure the development of sustainability, namely from the use of natural resources, equity aspects (social) political, social rights, education, health and technology. The concept of sustainability implies a link with the concept of carrying capacity which can be used as a measure of achieving sustainability of the process of tourism development. Utilization and development of the river needs to 
explore, study and understand the potential it has, as well as the obstacles to the participation of the local community.

\subsection{The Scope of Situation}

Ecotourism is a sub-component of sustainable tourism. The perception of the potential of ecotourism as an effective tool for sustainable development is the main reason why developing countries are now embracing it and incorporating it into their economic development and conservation strategies. In recent years, social economics has been considered an important source of social, economic and environmental wealth, and many scholars have focused their questions on this emerging field. However, only a few know the dominant environmental factors affecting the economic phenomena of society. In this study, analyzing how the factors of social innovation affect the implementation of social economy in the area. This research also applies inductive theory, building an empirical approach to conducting multi-case studies to develop theoretical propositions that enhance our understanding of the phenomenon. In the development of competitive tourism in the world is increasingly high business competition, nowadays digital education is needed more seriously in theory and practice. Every individual must begin to realize and be able to use free time to try digital businesses. And to educate entrepreneurship to students, to get more creative and innovative in the digital business opportunities that exist today, so they can create their own income to cover their lives (Urbano, et.al. 2010)

Tourism development is mainly based on social innovation, because social innovation is always an epistemic intervention (articulating various types of knowledge) and also a political intervention (because it chooses solutions to others and implements them through the level of governance) in certain social systems (Castro-Spila et al., 2015) Social innovation has been established as a third way to resolve market or state failures or both to integrate social groups into certain dynamics that are considered social welfare standards. Thus, when the integration and welfare mechanism fails, there is a situation at issue as a social demand that is not met. This particular problem is able to mobilize in many cases a set of resources (creative, financial, organizational, technological, political and cultural) organized as social innovation. From this point of view, social innovation is seen as a new product, process and method that, creatively and sustainably, offers better solutions for one or several social demands. In this way, social innovation implies changes in social practices of certain social systems (Phills, Deiglmeier \& Dale, 2012).

In the social innovation cycle the following capacities are activated: (a) Acquisition of external knowledge, this is, the capacity to identify and interpret social problems from monitoring social dynamics and access to diverse sources of ideas and knowledge; (b) the development of social innovation, that is, the capacity to incorporate and apply knowledge in the development of new products, processes or methods aimed at solutions to problems and social inclusion; (c) interpretation of the impact of social innovation, that is, assessment of the diversity of social impacts (impacts on target populations), diversity of organizational impacts (organizational learning derived from the application of social innovation), and diversity of sectorial impacts (effects of social innovation on several sectors such as health, education, etc.); (d) Governance, namely the capacity for inclusive development of social innovation. Governance reveals mechanisms of inclusion 
and participation of target populations of social innovation (social governance), strategic partners (governance between organizations) and sustainability of social innovation (sustainable governance) (Castro-Spila et al, 2015)

According to Beeton et al, (2006), in their further research arguing that the orientation of tourism development needs to put the facts and evidence of local community involvement, as the main consideration in developing the capacity and capability of the potential that exists in the community. This is done in order to improve aspects of tourism services and at the same time be able to realize the central role of the community, in various sustainable tourism development activities in accordance with the expectations and capabilities of the community itself. Local community participation is considered important for policy making in the development of regional tourism, and the usefulness or benefits to be gained by the community as an implication of the success of tourism activities.

\section{LITERATURE REVIEW}

Associated with the perspective and focus of this study, researchers sought some literature related to the Opportunities and Challenges of Sustainable Social Innovation. Recently (Chella \& Nicolopouloua, 2010), have proposed a definition, which highlights innovation at the core of the process: social entrepreneurship includes the activities and processes undertaken to find, define and exploit opportunities to increase social wealth by creating new businesses or managing existing organizations in an innovative way.

The main drivers of social enterprise are social problems that are dealt with in an innovative and entrepreneurial way. Social enterprises can offer innovative solutions to help solve problems of social integration, social dysfunctional behavior and socio-economic development. This shows the need for further research, especially to further test the model comparatively. According to (Damanik \& Janianton, 2013); (Boo, E. et al, 1990); (Nelson, \& Winter, 2004); (Eplerwood, M, 1999), in Indonesia in fact, tourism development is more facilitated by the state, whereas people tend to be passive. As a result, local capacity to respond to statesponsored innovations through the development of rural tourism faces many important problems, not in line with the goals and expectations of the government. In this study (Fuchs, Werner \& Walla, 2008); (Butler, 1996) adding that the inherent subjectivity of people's wrong perception, produces fear and becomes very vulnerable to harassment and overdoing, must be limited by practical relevance. Tourism development models and theories related to increasing visitor motivation are two ways that can be tried to explain and predict the impact of tourism on the host community and the existence of the environment. The rapid increase in the area of tourism is increasingly obtained for those who are successful in business but also some who are not successful. What is distinguished only because they are lucky or better with others who has not succeed. But there are also ways to help people who have not been successful. Speaking of which to make some of the work they need. And some new jobs will eventually reduce the unemployment rate. Benchmarks for the social welfare and economic life of a country can be seen from the size of the existing state unemployment. While economic progress is determined from the aspect of entrepreneurship. It is able to develop community. 
Tourism Research as one of the pillars of economic development plays an important role in foreign exchange growth and increasing regional income. However, this is not an easy job for a new city to develop tourism in its region, because it has to compete with other cities to introduce the city's tourism potential to the public, so prospective travelers know and are interested in coming. Large cities that are major players in economic growth must have a sale value that can be offered to a wide audience. One element of the success of a city can be seen from its success in providing a brand or brand that can distinguish it from other cities. In this case, marketing activities are needed to convey information about the existence of the city and highlight specific characteristics in the city. One way to deal with competition in the tourism sector is to carry city branding. (Simon, et al, 2017).

Research, development, and innovation are increasingly at the center of the political agenda as a tool to stimulate economic growth, with intellectual support from new understandings by economists from drivers of endogenous social change. In the European Union (EU), Europe's 2020 strategy includes the Navy flag Innovation initiative, which aims to turn Europe into a world-class science player, by establishing a joint European Research Area and completing or launching a priority development of European research infrastructure (RI). Other countries, including China, are planning large-scale scientific endeavors for the coming decades (Crosby \& Phillip, 2003).

The aspect of regional imaging of social innovation with awareness is the application of branding, without the support and embodiment of community social innovation in the development of tourism and services to tourists as well as cultural diversity and uniqueness of cultural activities supported in international events will be in vain. Perceptions of the image of a tourist destination affect satisfaction and intention to visit related locations in the future which of course depends on the ability of the tourist destination to provide unforgettable positive experiences gained during the tour (Beerli. \& Martin, 2004).

The process of creating innovations for Tourism Development in communication strategies must focus on a number of targets that can be identified by the company itself or with the help of a guide. One such target is identifying the right way to engage with customers with a combination of Brand Awareness, Brand Engagement, and Word of Mouth. Three main parts of the communication strategy are interrelated: Brand Awareness, Brand Engagement and Word of Mouth. The effectiveness of communication strategies (different combinations of Brand Awareness, Brand Engagement and Word of Mouth) can be measured by certain metrics or statistics. (Kazakulova, 2012).

Opportunities and challenges must be understood as a way to achieve competitive advantage in regional tourism development but can also be used to build communities, strengthen local identity and citizen recognition of their regional tourism development and activate all the forces of social capital. The purpose of this research is to find out how the process of social innovation and sustainable entrepreneurship in education as a regional tourism development strategy will be applied. Some of the benefits of this research include: Theoretically, this research can be a contribution of thought and enrich concepts for research science related to the development of regional branding through the organization of cultural events. Practically, this research is expected to provide input to local governments to create innovations and action plans that contain tourism 
development targets with branding and conduct a monitoring and evaluation phase to measure the success of the programs that have been implemented.

The innovation aspect of social capital is a collection of active relationships between people, from having awareness; trust, mutual understanding and shared values and behaviors that bind members in the network and community. It enables sustainable cooperation in the community. Social capital as well as a set of resources inherent in family relationships. And in social organizations, the community is useful for cognitive social development for children or adolescents. Resources are different for different people, and provide important benefits for children and adolescents in the development of their human social capital. Average social capital is a social network that has value, social contact in the community. (Cohen \& Prusak, 2001), (Coleman \& James C, 1994), (Putnam, 2000).

(Fukuyama \& Francis, 2000) stated that Social Capital such as the relationship of trust, norms and networks that can improve community efficiency by facilitating coordinated action, to encourage participation to act together more effectively to achieve common goals. Emile Durkheim is widely known as the main founding figure of 19th-century sociological thought, specifically interested in how social ties between people became the knot that united the broader order of society. Cause in society there is no good mechanical and organic solidarity. According to Durkheim, people do not become atomic bonds facing each other, but because members are united by bonds that are tighter and increasingly beyond the brief moment of such exchange. By giving exposure to trust grows hope in the community that is shown by honest behavior, orderly and cooperation based on norms that have been shared.

De Pillis, \& Reardon (2007) was stated at the community level, the sources of innovation and trust came from social norms that were already embedded in local social structures. Serving poor people in love, does not meet or help the needs of their consumers. Loving also means respect, including respecting them in solving their problems. Therefore, serving the poor does not mean providing something or facilities to make them dependent. But it opens up the possibility to solve their problems and to achieve a better life in a more humanistic social order. Trust is a hope that grows in a society that is shown by honest, orderly behavior and cooperation based on shared norms. At the disposal of resources the level of community trust comes from social norms that are already embedded in local social structures. For entrepreneurship programs, education has played an important role in developing entrepreneurial competencies and fostering goodwill for students.

Furthermore the development of individual competencies in business is also one of the most influential factors in the process of creating a new business, to increase growth and create success in business. (Berryman \& Frey, Murali, Mohani, \& Yuzliani, 2007). It should be understood that economic development includes community efforts to develop economic activities and also increase the level of community income. But overall economic development efforts also include social, political and cultural development efforts. Economic Development is generally defined as a process that causes the capita income of a society to increase in longterm debt (Sadono Sukirno, 1985). Meanwhile Prof. Simon Kuznets defines economic growth as the goal of creating long-term, increasing the ability of a country to provide more types of goods in the population's economy, and having 
the ability to grow in accordance with technological progress, as well as the institutional and ideological adjustments needed. (Jhingan, 1999).

(Min-Seok Cha, 2010) Stating that innovation, creation, is part of the entrepreneurial process in business creation that begins when business opportunities are discovered or created by newborn entrepreneurs. This process involves an improvised journey and overcoming uncertainty. There are many obstacles as well as interesting, encouraging, and driving forces that entrepreneurs may face along the way. It takes an internal drive and the power to solve this problem by taking entrepreneurial action to actualize new business potential for all opportunities. The series of autonomous, innovative, and improvised actions of entrepreneurs during the entrepreneurial process will consist of entrepreneurial journeys. This journey will be seen as a combination of the process of will and emergence transforming potential into actuality, namely the realization of opportunities.(Frank Martin Belz \& Julia Katharina Binder, 2015); and (Thompson, Strickland \& Gamble, 2006). The country's sustainable entrepreneurship is a stream of newborn research at the intersection of sustainable management and entrepreneurship. In recent years it has received increasing interest from researchers with different academic backgrounds. But it is not surprising for a new field of research, there are various definitions of sustainable entrepreneurship.

In general, there are two perspectives. One group of scholars, publishing in a sustainable management journal, emphasizes the concepts of sustainable development and triple bottom line, while entrepreneurial activities remain below. (Parrish, 2010), (Schlange, 2009), (Tilley, F., 2010).

Other undergraduate groups, which publish mainstream entrepreneurship journals, align triple line ideas with the perspective of the entrepreneurial process (Cohen \& prusak, 2001); (Dean \& McMullen, 2007), emphasizing individual relationships and opportunities. In line with the latter, we define sustainable entrepreneurship as recognition, development, and exploitation of opportunities by individuals to realize future goods and services with economic, social and ecological benefits (Cohen \& Winn, 2007). Recognition, development and exploitation of opportunities describe generic processes and entrepreneurial activities (sustainable). Economic, social and ecological benefits refer to the triple bottom line, which must be balanced in the face of ambiguity, contradiction and exchange(Cohen, Erik, \& Scott A Cohen., 2012)

(Prophet \& Kevin Lynch., 2006) there are eight steps in the development of city brand tourism or the location proposed in the CEO for the city, namely: 1) Establishing clear objectives of tourism innovation in city branding. In city branding several aspects are needed and must be considered as supporting factors. Among them are knowing the concepts and goals of the brand itself made by related parties. Goal setting can be done through the largest excavation potential in the city and serves as the basis of the city's imaging goals. 2) Understand target visitors. After setting a branding goal, it is necessary to market the city brand so that one city can become a marketable object. This process starts with a clear mind about the target audience. This target audience can be interpreted as a potential visitor. Hearing can consist of individuals, certain groups of people, or the general public. 3) Identification of the current brand image.

The main purpose in identifying brand image is to understand how the audience sees and assess the place so that between the factual conditions and desired 
conditions there are no gaps, so that city branding can build an image of the city in accordance with the identity of the city created. 4) Establish the identity of brand aspirations. Brand management starts with developing a unique brand identity that represents the brand's goals and promises to customers through an aspirational image. 5) Develop a position positioning assessment step. Positioning is how a brand with all the values it offers is always number one in the minds of consumers. The aim is to place the brand in the minds of consumers to maximize potential benefits. 6) Make a value proposition. The value proposition appears because the positioning step was successfully made. This aspect is important because it involves the reason why the target audience has to buy the product. 7) Running the brand strategy steps. In order for city branding to be successful so that the brand can be known to a wide audience, it is necessary to strategy one of them by designing media campaigns so that the message to be conveyed can be spread widely. The strategy can be primary or secondary communication. 8) Measure success. In implementing the city branding strategy, a way is needed to measure success.

Entrepreneurship is a creative and innovative effort to build value that is not yet available and can be enjoyed by many people. And that is dynamic behavior, to accept growth-oriented risk as creative survival. (Lambing, Peggy, and Charles R. Kuehl., 2012), (Arif F. Hadipranata, 2000), entrepreneurs are risk takers needed to set up and manage businesses and receive cash for financial gains. Furthermore (Kathleen, 2002) argues that entrepreneurs are people who organize, run, and bear the risk of work done in the business world. Entrepreneurship is the value manifested in behavior in the awareness of basic human resources, driving force, goals, tactics, tips, processes and business results (Achmad Sanusi, 1994).

Meanwhile, Enterprise is the value needed to start a business (initial phase) and business development (business growth) (Soeharto, 2010). So far Entrepreneurship is the process of creating something new at value using time and research effort, to assume the financial, physical, social risk that accompanies and accepts prize money produced, as well as satisfaction and touch on personal freedom. (Saidi Wahyu, \& Hartati Sofia, 2008).

Entrepreneurship is also a disciplined knowledge that studies values, skills and behavior in facing life's challenges to pursue opportunities with various risks that may be faced. (Suryono \& Agus, 2004) Entrepreneurship is further taken from words and business entrepreneurship. ("Entrepreneurship") Entrepreneur means warrior, role model, noble, and (business) is a business that means someone must do something to get wisdom. So an entrepreneur is someone who wants to do an example of working very hard. And there are other meanings of the big Indonesian dictionary: smart or talented people to recognize new products, determine how to produce, arrange and manage the organization's capital operations and enter the business market. Thus Entrepreneurs are creative and innovative people who are able to improve the welfare of society and the environment itself (Raymond \& McLeod, Anthony, ., 1995).

(Joseph Schumpeter., 2008), states that entrepreneurs are innovators who implement changes in the market through new combinations. New combinations can be designed in the form of: Introducing new products or new qualities; introducing new production methods; opening new markets; obtain a source of supply of new materials or components; and starting a new organization in an industry. So far (Joseph Schumpeter., 2008), Entrepreneurs are associated with the 
concept of innovation that is applied in a business context and relate it to any combination of resources. In the global era, Entrepreneurship in new businesses will begin and the growth of small businesses is seen by most countries as a means to increase the growth of gross national product, reduce unemployment and improve quality of life. Entrepreneurship offers individuals with the opportunity to build a successful career without having to join a great company with little ability to influence decisions. Many higher education institutions throughout the world have stepped forward to support entrepreneurship by developing programs that give the community the skills, knowledge, abilities and opportunities to become successful entrepreneurs and small business managers. These types of programs are available, but vary greatly.

Thus it can be simple that Entrepreneurship is an easy understanding as a systematic process of translating creative and innovative ideas into business processes on an ongoing basis, which is a productive business and able to respond to any changes that might occur. As we know that the aim of developing entrepreneurship is very complex. The whole systematic process of developing entrepreneurship must lead to goals and generate income or profits. The process of learning continuous innovation to achieve perfection can meet the demands of changing community benefits. In creating the most important business is understanding the need to find out the first opportunity in the field and its market segments, therefore it is necessary to conduct a survey or conduct a feasibility study. (Dharmawan, 2002)said, there are six functions of trust:

- Believe in self-confidence, work individual psychology. This attitude encourages people to believe that there is a decision to take after calculating the risk. At the same time, other people will believe in the same social action, so he finds the legitimacy of collective action.

- Cooperation, as an associative process, underscores the motivating relationship of trust and distrust of individuals. Furthermore, the spirit of cooperation will encourage high social integration.

- Simplification of work, which is done by trust increases the efficiency and effectiveness of social communities.

- Orderly functions as a way of encouraging the behavior of every individual that helps create an atmosphere of peace and reduces the possibility of social unrest. Maintaining cohesiveness of trust can help improve the social life of each component in a community to be integral and scattered.

- Social capital Trust serves as a driving force to jointly build shared interests. The central idea of Social Capital is to make social networking a very valuable asset.

Elkington (1997), a well-known sustainability practitioner and writer, there is a gradual mainstreaming of social innovation into the broader economy either through innovative partner ships between large companies and top social entrepreneurs or by the evolution of social entrepreneurship within corporate self. In their famous article "Creating shared value" (Michael Porter, 2015) emphasized the importance of socially oriented innovation in which businesses must create shared value with social stakeholders. Every company, as they begin to see decisions and opportunities through a shared value lens, will lead to new approaches that will result in greater innovation and growth for the company and thus greater 
social benefits. They must look back at their products and markets; redefining their productivity and value chain; and allows the development of local clusters.

Lundstrom \& Zhao, (2011) arguing that innovation based on social S\&T can play an important role in making innovation in China, and the missing part in this innovation study will be found throughout the world in the coming years. So far, there are no indicators that can measure the influence of 5000-year-old Chinese culture. It is interesting to see how (Andrew Ciesielski et al., 2009) formed a very realistic deduction from innovation inputs to output performance of various countries to show that although the input for innovation in China is far less than many other high-ranking countries such as the US and Singapore, China's output is large because of its manufacturing capabilities. Thus the ratio of performance output to innovation input for China provides a very large ratio that makes China stand out as the first among all other countries in this performance for innovation index.

Lundstrom \& Zhao, (2011) arguments are equally interesting where they claim that China may have many social innovations discounted by data. Data only counts more measurable scientific and technological innovations with patent figures in the fields of science and technology. Chinese manufacturing capabilities may have helped large Western companies that have outsourced their work to China, in developing products using innovative processes that are not recognized and described elsewhere.

\section{METHODOLOGY.}

In this study researchers used qualitative research, the first step is to conduct an inventory of research studies that can produce empirical data that is relevant to research. Determine the amount of relevant and quality data in accordance with the problems needed in the study. Identify the most important and reliable problems that determine opportunities and challenges in empowering community innovation, and implementing tourism development programs in the field. This research was conducted by combining several descriptive-evaluative approaches so as to obtain accurate and accountable information (confirmation) from the interview data, ask the questions directly with potential and available informants. Interviews and questionnaires are grouped into several aspects: (social, environmental, institutional, government, marketing) and expectations. So get more basic data, based on the problem to be investigated. Given in qualitative research, this research is about descriptive research, tends to use analysis.

The process and meaning of perspective with research subjects will be highlighted in this qualitative study. A literature study that is relevant to research can be used as a guide to focus on the problem. This research can be in accordance with the facts needed in the field. In addition, the bibliography can also be useful to provide an overview of the background of the research used by researchers as a discussion of research results. In this qualitative study, researchers depart from the selection of data that has a proposition to the research problem, utilizing relevant literature reviews and analysis of the underlying research (grounded research) as material that can provide an exact explanation in the research discussion, and finally can make new studies that are weighty and more valuable. 
To deepen the quality and benefits of this qualitative research, researchers took several studies and the opinion of (Kriyantono et al., 2012), stating that "qualitative research aims to explain phenomena in depth through deeper data collection. Qualitative research Emphasize the depth of data obtained by researchers. The deeper and detailed the data obtained, the better the quality of this qualitative research. In contrast to quantitative, objects in qualitative research are generally limited in number.

In this study, researchers participate in research activities to understand the conditions under study. Therefore, the results of this study requires depth of analysis from the researchers. In addition, the results of this study are subjective so they cannot be generalized.

\subsection{Data analysis}

In (Bungin \& Burhan, 2007), qualitative research is a type of research where the findings are not obtained through statistical procedures or other numbers. The dominant characteristics of qualitative research are (1) direct data sources in the form of natural situation data and researchers are key instruments, (2) descriptive, (3) more emphasis on the meaning of the process rather than the results, (4) data analysis is inductive, and (5) ) Meaning is a major concern in the research approach. Qualitative research can be used to examine people's lives, history, behavior, social movements, and so on. Cultural studies use methods that emphasize the relevance of culture to social problems and people's daily lives. Qualitative characteristics have actually been seen in every study of cultural studies, because qualitative research is a research paradigm with an interest in meaning and interpretation. In general, qualitative research is conducted by interview and observation methods. Through this method, researchers will analyze the data obtained from the field in detail. Researchers cannot examine the observed social conditions, because all reality that occurs is a unity that occurs naturally. Qualitative research results can also produce new theories or concepts if the research results conflict with theories and concepts previously used as studies in research.

The method used in collecting this research data uses:

- In-depth interview techniques for some information from several fields of tourism development both at home and abroad. The data will be collected as a description of information in the form and reveal the meaning behind that description.

- Observation is a data collection technique that is done by observing directly the existing field of practice. To obtain information or data that are objects of the study population associated with random research.

- Technical documentation where the technique is in the form of several documents or important information about organizations or individuals related to the research problem. Collecting information data through reports, records, and descriptions of supervisory duties and documents related to general operational areas.

\subsection{Work frame and model}

Conduct to the location of observation by studying data from existing literature and information from various parties related to the research object, and to obtain a general description of the situation of the research object. Based on 
observations formulating a research framework to compile data collection tools to facilitate the grouping of research results and help analyze data. Data analysis by interpreting the results of the analysis, and discussing by comparing aspects of Opportunities and challenges of Social Innovation Education and Entrepreneurship Sustainability as a Tourism Development Strategy with existing theories. The data source is the unit of analysis and also the observer unit, in this qualitative study the researcher carries out through research procedures that produce descriptive data, in the form of written or oral words from the selected informant or the person or actor observed. So that the data can be said to be valid or accurate as expected, which has credibility that can function as an observer unit or unit of analysis in this study. Data search is done by inductive methods, which depart from facts or general events and then generalize specifically. Whereas data management uses the reflective method, which reflects in accordance with the objectives of the study. Data sources used in this study are:

- Primary data is data obtained directly from the field of researchers, data obtained from interviews and questionnaires directly from respondents who have competency with this study, namely objective information from citizens as input for expected research.

- Secondary data. Secondary data in this study are general and collected data collected from second parties consisting of: administrative data, documents, photos, pictures, videos and reports of citizens and from related books related to this research.

In this qualitative research, the researcher departs from the selection of data that has credibility to the research problem, utilizes relevant theories and grounded research as material that can provide an appropriate explanation in the research discussion, and finally is able to create a new "theory" useful to be applied in community, by through:

- Research Approach using Data Sources (analytic units \& observer units), Data Triangulation Collection Techniques, interviewed with valid and competent informants with problems. Research instruments as measurement variables.

- Situation of research using Research Stages: (Preparation and submission of research proposals, Library Studies, Data Collection, Data Analysis, Preparation of Research Reports, Submission of Research Reports).

- The components of the reflective method are: (a) recording, (b) interpretation, (c) assessment, (d) description, (e) understanding; (f) analysis. Data Validity and Data Analysis Methods Using a). Research data collection techniques; b). Technical analysis of data, c). Data validity. 
Table 1: Flow of Qualitative Research

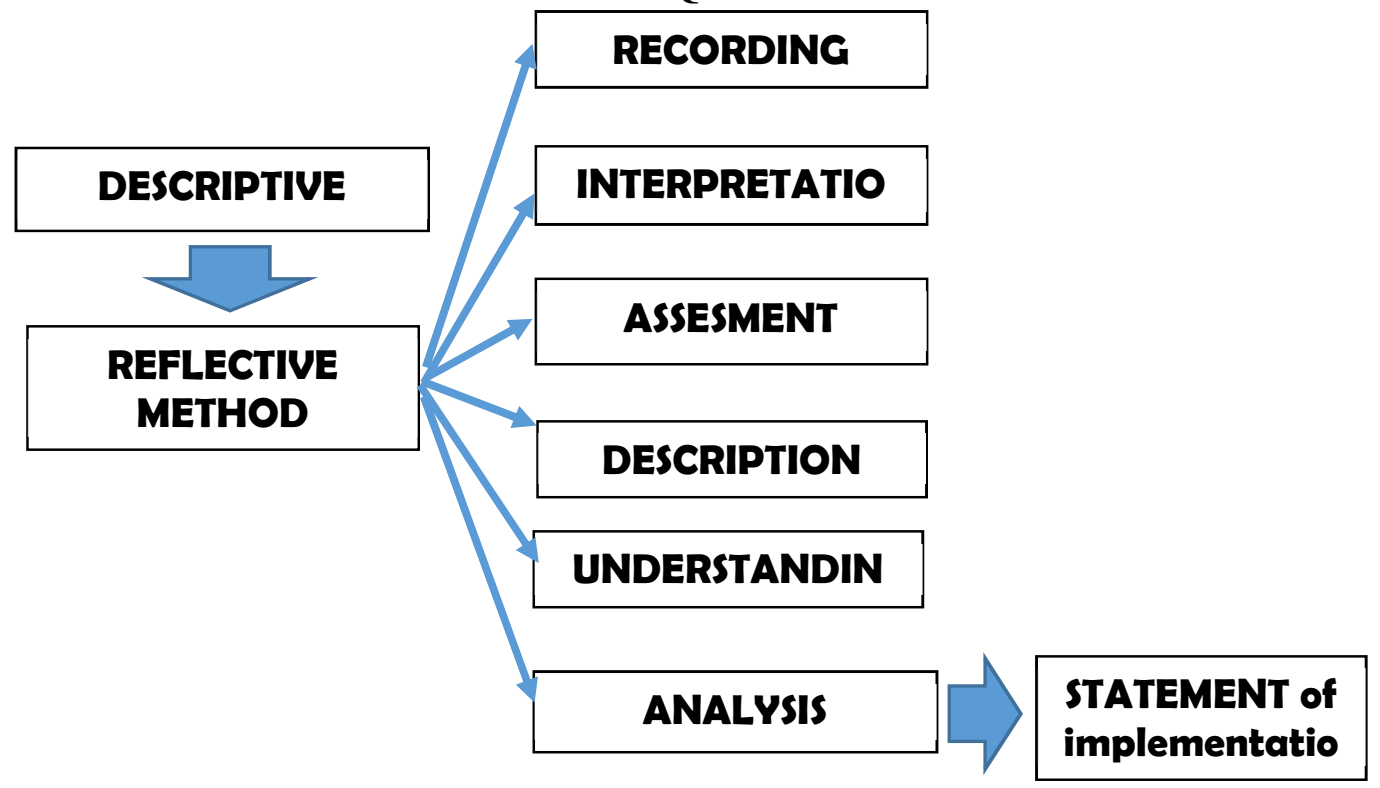

\section{RESULTS AND DISCUSSION}

\subsection{Problem statement in some aspects of social life}

In this discussion the researchers understood variously that the development of regional tourism was fully supported by the involvement of PENTA HELIX namely: Community, Government, Academics, the private community, and the role of Multimedia. Meanwhile according to Shane, (2003) [44], by realizing business opportunities to implement regional development strategies, the government must comply with important principles, especially in the aspect of regional development orientation. There are several important principles in implementing regional development strategies, and for achieving community welfare. Regarding business opportunities actually states that opportunities exist around us, it's just that there are some individuals who are able to see the situation as an opportunity that does not exist. This is caused by the information factor that has information that allows one to know. There are many opportunities where others do not ignore the situation.

Access to information is influenced by life experiences and social relationships such as:

- First, development must always be oriented towards community interests. The community area must be positioned as a subject while benefiting the parties of the programs and activities to be carried out. So the development program is directed at activities aimed at meeting the practical and strategic needs of community outcomes and impacts that can be felt directly by the community.

- Second, construction must be in accordance with community needs. Such as the process of development planning, implementation, and supervision of community involvement. All aspirations and needs of public areas must be accommodated and the results of development can be enjoyed directly and empowering the community itself.

- Third, construction must be in accordance with the native culture of the local community. Regional development already has a concern for customs, 
culture and norms that are maintained and developed in the community as local wisdom that enriches national culture within the framework of local, national, regional and global orientation.

- Fourth, regional development must be environmentally sound. So the management and utilization of local resources must be environmentally sustainable. This principle is to consider the impact of activities on the economic, social and cultural environment in short, medium and long term programs.

- Fifth, construction must not be discriminatory. This principle is important because after development it must be dissolved and spread evenly throughout the region, from cities to villages.

- Sixth, development must be based on partnership. This principle states that development must be carried out by all parties, without exception. Therefore, partnerships between public, private and government must be pursued continuously. Development must also be based on good governance.

- Clean government as the main support to achieve a prosperous society. And the development is also allocated a budget based on performance. Budget management is implemented based on a performance-based budgeting system.

Understanding the creative economy according to the United Nations Conference on Trade and Development (UNCTAD) in the "Creative Economy Report 2010" defines the creative economy as a concept that develops based on creative assets that have the potential to produce economic growth and development such as:

- Encourage increased income, job creation, and export income while promoting social inclusion, cultural diversity, and human development.

- This includes economic, cultural and social aspects that interact with technology, intellectual property, and tourism destinations.

- It can encourage increased income, job creation and export income while promoting social inclusion, cultural diversity and human development.

- This includes economic, cultural and social aspects that interact with technology, intellectual property, and tourism destinations.

- This is a series of knowledge-based economic activities with dimensions of development and cross-sectorial relations at the macro and micro-economic level as a whole.

- This is a viable development option for innovative multidisciplinary policy responses and inter-administrative actions.

- The essence of the creative economy is the creative industry.

Listening to this concept and understanding, realistic simple creative economic development means that people as talents must have creative and innovative ideas, and be able to create their own economic values that can change the quality of people's lives to be more prosperous. The creative economy depends more on individual creativity through ideas, creativity, and creative power to increase the economic added value of their work, thus creating new jobs and 
prosperity gradually or gradually. Thus, community empowerment that has many shortcomings and weaknesses must be empowered and requires more specific and in-depth treatment in the application of the empowerment and development of sustainable life creativity.

In a broader aspect, a sustainable tourism development program is needed, with a commitment to demand more effective, efficient, economical and productive local government implementation. Which means it must be optimized to use the concept of synergy and cohesion between the regional government and the community to jointly explore the potential, cultural richness and local wisdom in accordance with the characteristics of the region, in the corridor of the law. So that there will be an accelerated development and significant regional economic growth towards a prosperous society. Though human life is always filled with several problems that must be resolved properly, so it needs some:

- A life experience provides greater access to information and knowledge about opportunity discovery. Two aspects of life are experiences that increase a person's chances of finding opportunities, work functions, and variations in work.

- Social relations. An important step where one gets information from interactions with others. Some experts recommend that when you are afraid of entrepreneurship, starting a business as a group is an alternative. Therefore, the quality and quantity of social interaction will further enable individuals to form entrepreneurial groups. Important information when starting a business is information about location, market potential, sources of capital, labor, and how the organization is. The combination of a wide network and diversity of backgrounds will make it easier to get information.

- Innovation and Optimization of our Potential After business opportunities must be combined with our own potential. What competitive advantage do you have? What often happens in society is to choose a business that is trending at that time. This is good, but when the development process does not create innovation, it will be difficult to compete.

- Innovation as a strategic development. The benefits of having a good strategy and knowing what a good strategy should be achieved, there is no real 'process' for making a breakthrough strategy. In fact, researchers found that most strategists believed at the time, and there are still many who do it to this day, that the process for strategy formulation cannot exist. Interestingly enough, he thinks that the complexity associated with strategy formulation is too much to be controlled and that the formulation of strategy is, and will continue to be, an elusive art form that can only be mastered by a few talented individuals.

And set out to prove that this thinking is not true. With a background in Neuron Linguistic Programming (NLP), researcher knows that each set of activities or behaviors can be modeled, including the formulation of strategies and successful solutions. Then it starts to make a strategy formulation process that will produce a breakthrough strategy in every situation where the organization tries to formulate a business, product or operational strategy.

The first step in this effort is to uncover universal principles that are applied by organizations when they succeed in creating breakthrough strategies. To complete this task, it is necessary to apply applied pattern detection techniques that 
are often used in physics, NLP, and other behavioral sciences. After years of observation, I can detect patterns that have proven to be the driving force for the creation of a universal structure for strategy formulation. Through ongoing testing, it is verified that this pattern exists in every situation where the organization creates a successful strategy. It is at this point that I know the process of strategy formulation will develop. Since then, many other obstacles have been overcome in how to create the process of formulating an advanced strategy: important elements of the formulation of the strategy have been established; a method for collecting related information has been established; progress is made in the areas of gathering, comparing and positioning requirements; and the tools needed to process this information are created. Organizations can base company strategies and their products on internal objectives such as cost reduction or quality improvement. They can choose to react to managers who believe that organizations must do things differently. Given the increasingly competitive nature of most businesses and the emergence of global markets, a reactive approach to strategy formulation may be a recipe for failure.

\section{The Field of sustainable business}

Peter Drucker (1996) entrepreneurship experts state that in starting a business or an innovation that is carried out it is advisable to focus starting from small things from the resources we have. For example Vidi Catering in Yogyakarta where the founder has a bachelor background in agricultural technology, and a food processing department. Formerly started a culinary business for dormitories and students around the campus. Because of basic knowledge in the field of food processing, it can successfully develop the Catering, Hotel and now Convention Hall businesses with wedding packages and event organizers.

In the area of entrepreneurship, sustainable business will require several qualifications:

The role of entrepreneurship, based on the ideas of entrepreneurship and entrepreneurship above, the role of entrepreneurship can be defined as:

- One way out to solve employment problems (reduce unemployment). Also the national economy without burdening the government and society.

- Increase income and welfare of the community. Increase productivity of sustainable production factors.

Entrepreneurial Characteristics

In the opinion of By grave (1994) [46], the characteristics of entrepreneurship known

are:

(1) Dream (Vision for the Future)

Entrepreneurs must have a vision or point of view into the future to improve and develop their business and have the ability to complete its mission.

(2) Decisiveness (Quick Decision) Entrepreneurs are people who can work quickly to produce something. It can also make decisions quickly, accurately in calculations, in order to succeed in developing a business.

(3). (Implementing Decision) Entrepreneurs in making decisions will immediately follow. Activities are implemented as soon as possible with full calculation. He did not want to delay a good opportunity in business. The world of entrepreneurship is a world full of uncertainties while information is owned by 
people who are going to start a small business. Therefore, an entrepreneur must be willing to take risks and have excessive self-confidence is very necessary.

(4). Do it first, first, if there is a problem, just find a way out. Facing the problem of unemployment, training, entrepreneurship education through life skills education programs or other development programs that involve the community must be seriously implemented by the government or government partner institutions such as foundations or NGOs. Such programs must be entirely oriented towards learning outcomes to create a generation of entrepreneurs. Such an objective cannot, of course, be carried out with the current program model which is only oriented towards strengthening material and skills, but without the support of mental reinforcement and values in learners or new entrepreneurs.

Yoeti, (2006), also stated that tourism development planning includes: (1). Give direction; (2). Guiding cooperation; (3). Creating coordination; (4). Guaranteeing achievement; (5). To minimize risk: (6). Encourage the implementation of work. In the seminar on spatial renewal, for the improvement of life in the region, a tourism management approach is needed. Wiendu, (2010) provides details that in the development of tourism more broadly as follows: (1). Give the right direction for the development of tourism resources owned. So that tourism is expected to grow in a sustainable manner, have competitiveness for regional development, and can improve the welfare of the community. (2). Regulate the role of each pentahelix activist across sectors so as to encourage the development of ecotourism in a energetic and integrated manner. (Jhingan, 1999) (Kuznets \& Simon, 1999) defines that economic growth as a goal of long-term increase in creating the ability of a country to provide more and more types of economic goods to its population, this capability grows in accordance with technological progress, as well as institutional adjustments and ideological requirements. (Jhingan ML, 1999)

Competency development between individuals as entrepreneurs is also one of the most influential factors in the process of creating new businesses, in promoting growth, and creating success in a business venture that is in the community. (Berryman, J. C, \&. Frey; Murali, Mohani, \& Yuzliani, 2007). The ability to make innovations and the courage to apply innovations in new businesses that are built to open jobs, reduce unemployment, and improve the welfare of the community. The higher the number of entrepreneurs, the higher the economic growth (De Pillis, E., \& Reardon, K. K., 2007).

For example now with the increasing presence of Domestic Tourists in Yogyakarta, hotel occupancy rates are high, events are getting better, at every event such as seminars, workshops, meetings, tours, and exhibition programs (MICE), can provide great opportunities for people to open a business. Like the catering business, a small food business from Yogyakarta or traditional food, which is sold to domestic tourists or can be stored in several shops or shops with a consignment system. The number of shops, stalls, which provide Yogyakarta special food, as well as souvenirs of businesses scattered everywhere. The Yogyakarta aspect is a university town, so people can move to several catering businesses, food stalls, laundry businesses, and more sophisticated with online businesses (which don't require a lot of facilities and personnel). However, businesses must be aware of the wants and needs and purchasing power of prospective buyers. Special interest on 
Javanese culture event is Grebeg Gunungan as a special business attraction in Yogyakarta.

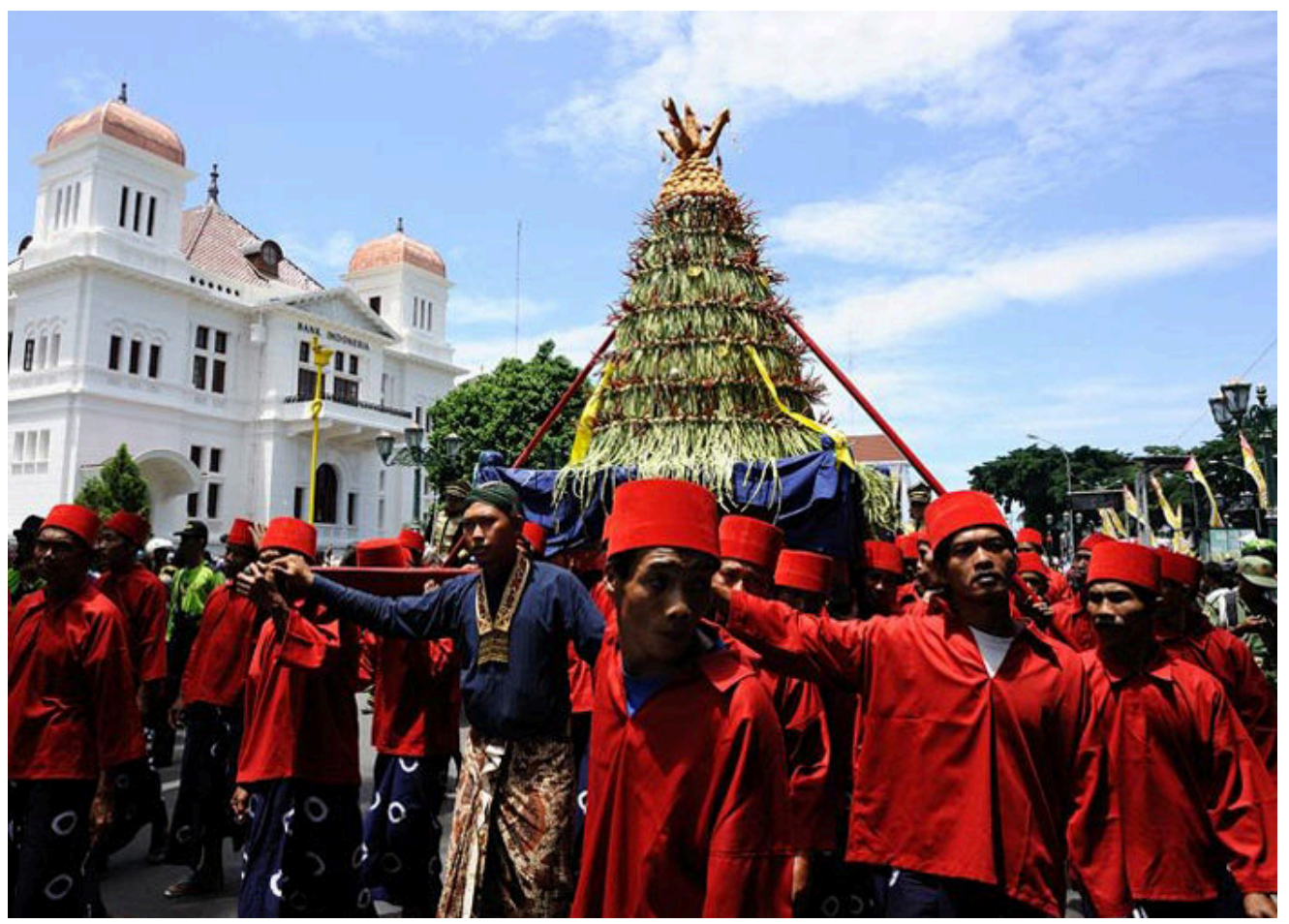

Image: Uniqueness of Grebeg Maulud event in Yogyakarta Indonesia (Source: Yogyess.com 2019)

In this business, one must be honest, determined, determined, more creative and innovative to pursue business. Dare to create products that are not there, and certainly can be enjoyed by many people. One must have a vision of the future with new ideas of creativity for business development and be more involved or utilize the resources of the surrounding community and environment with laborintensive systems that can support more strongly, and can sustain sustainable business prospects.

Opportunities and challenges with the development of Tourism in many big cities as well as Yogyakarta in particular, the increase in domestic tourists has encouraged the development of various businesses that are increasingly prevalent in Yogyakarta.

Yogyakarta opportunity as a student city, has made many students study in Yogyakarta, triggering the development of technology that was created by the business. Counter hand phone is a business today. But if they don't have a competitive advantage, for example after sales service, competitive prices, goods or services in general, it's difficult to grow a business. Someone comes to the store to buy a mobile phone, mostly because of information that has been obtained before either by word of mouth or from the newspaper. Likewise, culinary business ventures that grow in line with business growth as hotel accommodations in Yogyakarta, if they are not able to maintain the quality of products, the services will be abandoned by consumers.

Business services and knowledge-based education (knowledge intensive service) in Yogyakarta is an alternative business that has a competitive advantage. 
They established business courses, private courses (Prima Gama, Newton) as well as financial consultants, management consultants, engineering consultants and others, because of the provision of competencies, abilities, and practical knowledge that they had mastered. Therefore, this business model must be developed entrepreneurship at the university. Students are encouraged to conduct research in accordance with the field of science to have new knowledge and can be used by the community.

\section{CONCLUSION}

In the development of tourism, social community innovations have been studied which maintain the creativity of the survival of the local community itself. And by increasing human capital in entrepreneurship education get opportunities and challenges to create job creation and also the development of social welfare both now and in the future in Tourism Development. By providing these values now as basic entrepreneurs began to erode by growing technological progress and acculturation of foreign cultures that come to our country. The entrepreneurial spirit must be nurtured since childhood. It is regrettable that there are still many parents who want their children to seek the possibility of a degree in the highest education. Maintaining the principle and doctrine that smart schools with achievements will lead to success. Printed children are needed by high-paying community workers. Thus in the world of entrepreneurship, education does not prioritize theory but also the application of how to create innovation and creativity in business for future research. In addition to their potential in terms of knowledge, they need to optimize student motivation and personality aspects to become entrepreneurs.

Characteristics from the perspective of entrepreneurial psychology really get the picture to achieve innovation, creativity and some encouragement in doing business to succeed. Therefore, the extent to which students can develop their selfmotivation must be highly optimized with psychological potential to seize the opportunities and challenges of Tourism growth. Behave and dare yourself to take a change and create or start a new business in Tourism Development. With entrepreneurship education programs will be able to produce independent human social innovation and sustainable human capital.

Entrepreneurship education allows one to see challenges from various holistic aspects comprehensively. Improving entrepreneurship in the education curriculum will enrich the national education system and have an impact on the growth of successful entrepreneurs. In the future people will improve their lives with innovation and dare to create new jobs, and take the opportunity to reduce poverty and get a better social life in Tourism Development.

\section{REFERENCES}

Achmad Sanusi, (1994). Menelaah Potensi Perguruan Tinggi Untuk. Membina. Program Kewirausahaan. In Jakarta: Erlangga.Yogyakarta: Andi.

Andrew Ciesielski, Taylor, Ida Zahrina, \& Said Zul Amraini. (2009). Techniques and Analysis ",.

António Guterres Secretary-General of the United Nations. (2019). TheSustainable-Development-Goals-Report-2019.

Https://Unstats.Un.Org/Sdgs/Report/2019/. 
Ardiwijaya. (2004). Peran industry pariwisata Berkelanjutan dapat diartikan Kajian dari Aspek Lingkungan dan Sosial, Media Bina Ilmiah Lpsdimataram.

Arif F. Hadi Pranata, (2000). Peran Psikologi di Indonesia,. UGM.

Ashley, \& UNWTO. (2002). "Community views of ecotourism." Annals Tourism Research, 35(2), P.418-468.

Beerli \& Martin. (2004). Factors Influencing Destination Image. Mediating Role of Customer Satisfaction. European Journal Annals Tourism

Beeton, Wall, \& Mathieson. (2006). Tourism: Principles, Practices, Philosophy Edition. John Wiley.

Berryman, J. C, B., \& .Frey; Murali, Mohani, \& Yuzliani, (2007). Half the Human Experience: The Psychology of. Women. Gramedia Pustaka Utama.

Boo, E, Lindberg, K, \& Hawkins, Donald E. (n.d.). Ecotourism Planning for Protected Areas. The Ecotourism Society, North Bennington, 1993.

Bungin, \& Burhan. (2007). Metodologi Penelitian Kualitatif. Raja Grafindo Persada.

Butler. (1996). Harian Kompas, Sabtu (12/11/2016). International Journal of Tourism Research.

Castro-Spila, Unceta, \& Westley. (2015). Social innovation indicators. Fronti Published Online: 12 Jan 2016, Pages 192-204.

Chella, E., \& Nicolopouloua.., K. (2010). Social entrepreneurship and enterprise: International and innovation perspectives. A Small Business Research Centre, Kingston University, London, UK; Management School, University of Southampton, Southampton, UK.

Cohen, Erik dan Scott A Cohen. (2012). Authentication: Hot And Cool. Annals of Tourism Research., 39 (3): 1295-1314.

Cohen, \& prusak. (2001). Social Capital. PT Gramedia Pustaka Utama.

Cohen, \& Winn, (2007). Market imperfections, opportunity and sustainable entrepreneurship. Journal of Business Venturing, 29-49.

Coleman, James C. (1994). . A Rational Choice Perspective on Economic Sociology”. The Handbook of Economic Sociology, diedit oleh Smelser, Neil J dan Richard Swedberg.

Crosby, \& Phillip. (2003). Filosofi Baru Tentang Manajemen Mutu Terpadu Abad 21 "Kiat Membangun Bisnis Kompetitif." Jurnal Ventura, Vol. 8, No.

Damanik, \& Janianton. (2013). Perencanaan Ekowisata. Pustaka Pelajar.

David Urbano, \& 5. (2010). Analyzing Social Entrepreneurship from an Institutional Perspective: Evidence from Spain| Published on Line: 22 Mar 2010, Pages 54-69.

De Pillis, E., \& Reardon, K. K. (2007). The influence of personality traits and persuasive messages on entrepreneurial intention: A cross-cultural comparison. Career Development International, 12, 382-396.

Dean, \& McMullen, (2007). Theory of sustainable entrepreneurship: Reducing environmental degradation through entrepreneurial action. Journal of Business Venturing, 22, 50-76.

Dharmawan, M. (2002). Penguatan modal sosial untuk perlindungan sosial. The Journal of Environment.

Effendi. (2003). Telaah kualitas air Bagi Pengelolaan Sumber Daya dan Lingkungan Perairan. Penerbit Kanisius. 
Elkington. (1997). The Triple Bottom Line of 21 st Century Business Cannibals With Forks". Cannibals with Forks.

Eplerwood, M. (1999). Succesfull Ecotourism Bussiness. The Right Approach, Kota. Kinibalu Sabah.

Frank MartinBelz, \& Julia Katharina Binder. (2015). Sustainable Entrepreneurship: A Convergent Process Model. Journal Business Strategy., First published: 25 February 2015.

Fuchs, K, Werner.A \& Wallau, F. (2008). Entrepreneurship education in Germany and Sweden: what role do different school systems play? Journal of Small Business and Enterprise Development, 15, 365-381.

Fukuyama, \& Francis, (2000). Social Capital dalam Harrison, Lawrence E dan Samuel P Huntington, Culture Matters, How Values Shape Human Progress. Basic Books.

Jhingan M.L. (1999). Ekonomi Pembangunan dan Perencanaan, Raja Grafindo. Persada.

Joseph Schumpeter. (2008). Theory of Economics, innovation market power dynamic. Https://Strategika.Wordpress.Com/2008/05/17.

Kathleen, (2002). Basic Concepts in Neuroscience a Student's Neurobiology. In Malcolm. Slaughter (ed). Gramedia Pustaka Umum.

Kazakulova, \& Yulia. (2012). Communication Strategies via Social media: The Case Study of Tomorroland Http://Urn.Kb.Se/Resolve?Urn:Nbn:Se:Hj:Diva-18412.

Kriyantono, Rachmat, Abdullah, \& Zulhamri. (2012). Perception of Public Relations. Erlangga.

Kuznets, \& Simon. (1999). Teori Pertumbuhan Ekonomi”. ... Journal of Economics, Yogyakarta: BPFE. Bappeda. 2013.

Lambing, Peggy, and Charles R. Kuehl. (2012). Journal of Personality and Social Psychology,. Journal of Small Business Management. 45-61. ., 55 (6), 9911008.

Lundstromm, \& Zhao, C. (2011). A Study On Factors Affecting Turnover Intention Of Hotel Employees. Asian Economic Google Scolar.

Michael Porter. (2015). Competitive-Advantage-Creating First Published His Ideas on Generic Strategies in His 1985 Book Entitled.

Min-Seok Cha, \& Zong-TaeBae, (2010) the entrepreneurial journey: From entrepreneurial intent to opportunity realization. The Journal of High Technology Management Research, Volume 21,(Issue 1, 2010,), Pages 3142.

Nelson, \& Winter, (2004). Teori berbasis sumber daya keunggulan posisi relatif terhadap evo economy lutionary. Jurnal Manajemen 27 (2001) 643-650.

Nuryanti, Wiendu. (2010). Pembaharuan penataan ruang untuk perbaikan kualitas hidup didaerah dengan pendekatan kepariwisataan. Paper Rapat Kerja Nasional IA-ITB, Yogyakarta.

Parrish. (2010). Sustainability-driven entrepreneurship: principles of organization design. Journal of Business Venturing, 25(5), 510-523.

Phills, Deiglmeier, \& Dale, W. and A. (2012). Social innovation indicators: Innovation: The European [Google Scholar]

Prophet, \& Kevin Lynch. (2006). Branding Your City. The City Image and its Elements. Gramedia Pustaka. Utama. 
Putnam. (2000). Modal sosial dan mekanisme adaptasi masyarakat. Jurnal Sosiologi, Vol. 20,

(No. 1, Januari 2015), 81-97.

Raymond, \& McLeod.Jr, Anthony, (1995). Sistem Informasi Manajemen. Penerbit PT. Prenhalindo Gramedia. Pustaka Utama.

Sadono Sukirno. (1985). Ekonomi Pembangunan. Gramedia Pustaka Umum,.

Saidi Wahyu, \& Hartati Sofia, (2008). Kewirausahaan. Enno Media.

Schlange,. (2009). Stakeholder Identification in Sustainability Entrepreneurship: The Role of Managerial and Organisational Cognition. Greener Management International, 55, 13-32.

Sekartjakrarini, (2007). Penyusunan desain wisata minat khusus. Repositori.Ipb.Ac,Id.

Simon Anholt, Moilanen, \& Rainisto. (2017). Influence of City Branding, Brand Identity, and Brand Image on Visiting Decision to Pekalongan City. Jurnal Bisnis \& Manajemen,

Vol. XVIII (1), 34.

Soeharto. (2010). Kewirausahaan dan Manajemen Usaha Kecil,Yogyakarta, BPFE.

Soetomo. (2006). Strategi-strategi Pembangunan Masyarakat,. In Yogyakarta: Penerbit Pustaka Pelajar.

Suryono, \& Agus. (2004). Pengantar Teori Pembangunan. .. Alfabeta.

Tarmuji, \& Tarsis. (2000). Prinsip-prinsip Wirausaha. Liberty.

Thompson, Strickland, \& Gamble, J.E. (2006.). Crafting and executing strategy: The Quest for Competitive Advantage. McGraw-Hill. New York, 2006.

Tilley. (2010). Sustainable Entrepreneurship: Entrepreneurship Theory and Practice, 35(4), 631- 652.

Widodo. (2008). Sustainable Water Resources Management with Special Reference to Rainwater Harvesting: Case Study of KartaManTul, Java, Indonesia. Dissertation, Universität Karlsruhe. Germany.

Yoeti. (2006). Perencanaan dan Pengembangan Pariwisata. Jakarta: Pradnya Pramita. 